\title{
IMPLEMENTASI MODEL PICTURE AND PICTURE UNTUK MENINGKATKAN PEMAHAMAN KONSEP JENIS MATA PENCAHARIAN DI LINGKUNGAN SEKITAR BAGI SISWA SEKOLAH DASAR
}

\author{
Amira Henny Mahmudah, Imaniar Purbasari, Ika Ari Pratiwi, dan \\ Erik Aditia Ismaya
}

Universitas Muria Kudus

Email: nymaamira@gmail.com

\section{Info Artikel}

Sejarah Artikel:

Diserahkan 13 Agustus 2020

Direvisi 16 Agustus 2020

Disetujui 21 April 2021

Keywords:

Picture and picture,

Conceptual understanding,

Types of livelihoods material

\begin{abstract}
The objectives of this study were 1) to analyze the improvement of teacher teaching skills in improving students 'conceptual understanding using the picture and picture model of learning on the material types of livelihoods in the surrounding environment 2) to analyze the improvement of students' conceptual understanding using the picture and picture model on the type of livelihood in surrounding environment.

The research method used is classroom action research. This research was conducted in two cycles, each of which consisted of planning, acting, observing, and reflecting. The research subjects were the fourth grade students of SD 2 Jojo Kudus with a total of 20 students. The data sources of this research are teachers, students. Data collection techniques include observation techniques, and tests. The data analysis used was qualitative and quantitative data analysis. Quantitative data analysis was used to calculate the increase in students' conceptual understanding using the picture and picture model.

The results showed that an increase in teacher teaching skills occurred in every indicator between cycle I to cycle II. The teaching skills of teachers in cycle II have increased and in general the teachers have implemented the steps of the picture and picture learning model properly. The application of the picture and picture model can also improve students' conceptual understanding skills at SD 2 Jojo Kudus in understanding types of livelihoods. The students' understanding of the concept of social studies content in the first cycle obtained a success percentage of $75 \%$ with very good criteria, then the second cycle obtained a percentage of $94 \%$ with very good criteria
\end{abstract}

\begin{abstract}
Abstrak
Tujuan penelitian ini yaitu 1) menganalisa peningkatan keterampilan mengajar guru dalam meningkatkan pemahaman konsep siswa menggunakan model pembelajaran model picture and picture pada materi jenis mata pencaharian di lingkungan sekitar 2) menganalisa peningkatkan pemahaman konsep siswa dengan menggunakan model picture and picture pada materi jenis mata pencaharian di lingkungan sekitar.

Metode penelitian yang digunakan yaitu penelitian tindakan kelas. penelitian ini dilaksanakan selama dua siklus, dimana setiap siklusnya terdiri atas perencanaan, tindakan, pengamatan, dan refleksi. Subjek penelitian yakni siswa kelas IV SD 2 Jojo Kudus dengan jumlah 20 siswa. Sumber data penelitian ini yakni guru, siswa. Teknik pengumpulan data meliputi teknik observasi, dan tes. Analisis data yang digunakan yaitu analisis data kualitatif dan kuantitatif. Analisis data kuantitatif digunakan untuk menghitung besarnya peningkatan pemahaman konsep siswa dengan model picture and picture.

Hasil penelitian menunjukan bahwa terjadi peningkatan keterampilan mengajar guru terjadi di setiap indikator antara siklus I ke siklus II. Keterampilan mengajar guru pada siklus II terjadi peningkatan dan secara umum guru sudah menerapkan langkah-langkah model pembelajaran picture and picture dengan baik. Penerapan model picture and picture juga dapat meningkatkan kemampuan pemahaman konsep siswa siswa di SD 2 Jojo Kudus dalam memahami jenis mata pencaharian. Pemahaman konsep siswa muatan IPS siklus I memperoleh persentase keberhasilan $75 \%$ dengan kriteria sangat baik, kemudian siklus II memperoleh persentase $94 \%$ dengan kriteria sangat baik
\end{abstract}




\section{PENDAHULUAN}

Semua manusia pasti memiliki kebutuhan dalam hidupnya. Kebutuhan primer seperti sandang, pangan, dan papan memaksa manusia untuk bekerja. Menurut Poerwadarminta (2002) kerja adalah melakukan sesuatu. Sedangkan menurut Ndraha (1991) kerja adalah proses penciptaan atau pembentukan nilai baru pada suatu unit sumber daya, pengubahan atau penambahan nilai pada suatu unit alat pemenuhan kebutuhan yang ada.

Bekerja sebagai proses pembentukan nilai baru pada sumber daya membentuk jenis-jenis pekerjaan yang ada di sekitar. Jenis-jenis pekerjaan seperti bertani, berkebun, dan beternak merupakan pekerjaan yang memanfaatkan sumber daya alam. Sumber daya alam dapat dibedakan menjadi sumber daya alam yang dapat diperbarui (renewable resources) dan sumber daya alam yang tidak dapat diperbarui (non renewable resources).

Sumber daya alam yang dapat diperbarui sumber daya alam yang memiliki kemampuan untuk mempertahankan atau mengganti diri (reproduksi) melalui proses alami atau dengan campur tangan manusia dan manajemen yang tepat. Contoh sumber daya alam yang dapat diperbarui yakni sebagian besar tanaman dan hewan-hewan, air, dan udara. Adapun sumber daya alam yang tidak dapat diperbarui yakni sumber daya alam yang tidak memiliki kemampuan untuk mempertahankan atau mengganti diri (reproduksi) baik tanpa atau dengan campur tangan manusia. Sebagian besar dari sumber daya ini sedang dieksploitasi melebihi kemampuan pulihnya, walaupun ada yang dapat digunakan berkali-kali seperti minyak bumi, mineral, dan kayu hutan tropis. Sumber daya alam tersebut, terutama sumber daya alam yang tidak dapat diperbarui jika terus dieksploitasi lama kelamaan akan habis, sedangkan kebutuhan manusia akan tetap ada.

Jenis-jenis pekerjaan atau yang biasa disebut mata pencaharian yang dapat memanfaatkan sumber daya alam bisa kita temui di lingkungan sekitar. Berbagai jenis mata pencaharian sebagai salah konsep pada mata pelajar Ilmu Pengetahuan Sosial di sekolah dasar yang harus dikuasai oleh peserta didik ternyata tidak mudah dipahami.

Vivi, dkk (2012) berpendapat bahwa pemahaman konsep merupakan proses menerjemahkan, menafsirkan, dan menyimpulkan suatu konsep berdasarkan pembentukan pengetahuanya sendiri, bukan sekedar menghafal. Pemahaman konsep mempunyai peranan yang sangat penting dalam proses pembelajaran dan merupakan dasar dalam mencapai hasil belajar yang memuaskan untuk siswa. Handayani, dkk (2015) berpendapat bahwa pemahaman konsep adalah kemampuan seorang siswa dalam menyerap arti dari suatu ide abstrak dan dapat menjelaskan fakta dari pengetahuan yang ia milki. Pemahaman konsep dapat diartikan kemampuan menyerap arti dari materi atau bahan yang dipelajari.

Berdasarkan observasi yang dilakukan peneliti pada guru dan siswa kelas IV di SDN 2 Jojo pada tanggal 15 Juli 2019 diketahui bahwa penyebab rendahnya kemampuan pemahaman konsep berbagai jenis mata pencaharian pada siswa yaitu karena kurangnya minat membaca siswa dan sikap siswa yang tidak fokus atau gaduh dalam mengikuti pembelajaran. Sementara itu dari sisi guru ditemukan bahwa guru hanya menggunakan metode pembelajaran yang sama yaitu ceramah dan jarang menggunakan model pembelajaran kooperatif saat mengajar.

Persoalan rendahnya kemampuan pemahaman konsep siswa dalam materi jenis mata pencaharian tersebut diatas perlu dicarikan solusi sesuai dengan kondisi dan situasi peserta didik, kemampuan guru, dan sekolah. Oleh karena itu peneliti tertarik untuk melakukan riset tindakan kelas sebagai solusi untuk mengatasi rendahnya kemampuan pemahaman konsep tersebut.

Peneliti memilih menggunakan model pembelajaran picture and picture sebagai variabel proses dalam upaya untuk mengatasi rendahnya kemampuan pemahaman konsep. Johnson and Johnson (dalam Djamarah 2006) menyebut bahwa model pembelajaran picture and picture adalah pembelajaran mengandalkan gambar sebagai media dalam proses pembelajaran.

Pemilihan model pembelajaran picture and picture pada riset ini senada dengan penelitian Agustina, Utaminingsih, dan Purbasari (2014), riset Fadli, Murtono, dan Purbasari (2016), penelitian Triyanto, Sucipto, dan Ismaya, (2017), riset Irawan AS, Setiawan, dan Ismaya (2018), dan penelitian Nurhidayat, Purbasari, dan Ahsin (2019) yang sama-sama menggunakan model pembelajaran picture and picture sebagai salah satu variabel penelitian. Diharapkan, penerapan model pembelajaran picture and picture membuat siswa lebih tertarik pada materi yang diajarkan oleh guru, mampu bekerja sama dengan kelompok sehingga mereka lebih mudah mengingat kembali materi yang telah dipelajari. Berdasarkan latar belakang diatas maka tujuan penelitian ini yaitu 1) menganalisa peningkatan keterampilan mengajar 
Amira Henny Mahmudah, Imaniar Purbasari, Ika Ari Pratiwi, dan Erik Aditia Ismaya PICTURE AND PICTURE UNTUK MENINGKATKAN PEMAHAMAN KONSEP JENIS .... WASIS : Jurnal Ilmiah Pendidikan. Volume 2 , Nomor 1, Mei 2021, hlm. 21-28

guru dalam meningkatkan pemahaman konsep siswa menggunakan model pembelajaran model picture and picture pada materi jenis mata pencaharian di lingkungan sekitar 2) menganalisa peningkatkan pemahaman konsep siswa dengan menggunakan model picture and picture pada materi jenis mata pencaharian di lingkungan sekitar.

\section{METODE PENELITIAN}

Metode penelitian yang digunakan yaitu metode penelitian tindakan kelas. Model penelitian yang diterapkan yaitu model Kemmis \& Mc Taggart. Adapun model PTK yang dimaksud memuat adanya beberapa langkah yang berkesinambungan yang disajikan dalam gambar berikut.

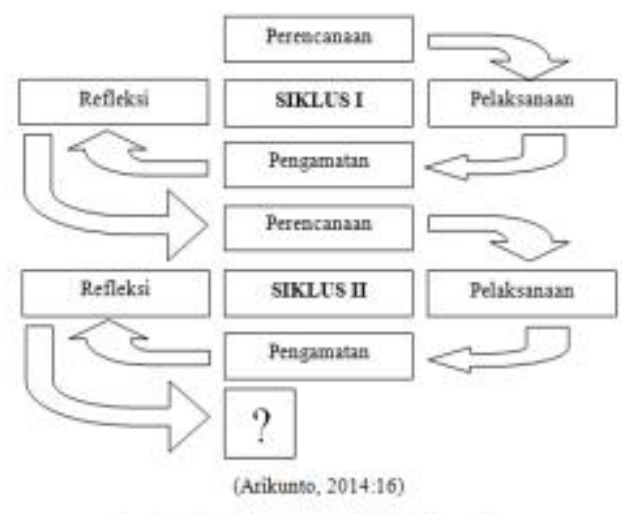

Gambar 3.1 Prosedur penelitian tindakan kelas

Dari gambar skema model PTK diatas dapat dijabarkan sebagai berikut 1) perencanaan, tahap awal yaitu perencanaan penelitian melakukan observasi dan wawancara terlebih dengan wali kelas IV bertujuan untuk mengetahui kendala dalam proses pembelajaran di kelas dan untuk mengetahui karakteristik siswa, 2) pelaksanaan, tindakan penelitian dilaksanakan pada kelas IV di SD 2 Jojo Kudus. Tindakan yang dilakukan yaitu penerapan RPP dengan model pembelajaran Picture and picture untuk meningkatkan pemahaman konsep siswa, 3) pengamatan, pengamatan dilakukan pada waktu KBM berlangsung agar hasil pengamatan sesuai dengan kenyataan yang ada, 4) refleksi tahap refleksi dilakukan untuk mengetahui kesalahan dan kekurangan yang masih terjadi dalam proses pembelajaran tersebut untuk acuan disusunnya kembali skenario pembelajaran yang lebih efektif pada kegiatan siklus berikutnya.

Tempat atau setting dalam penelitian tindakan kelas kali ini yakni SD 2 Jojo yang terletak di Jln. Karang Anyar No. 01 Desa Jojo
RT 01 RW 1 Kecamatan Mejobo Kabupaten Kudus 59381, Jawa Tengah.

Subjek dalam penelitian ini merupakan siswa kelas IV SD 2 Jojo yang berjumlah 20 siswa yang terdiri dari 11 siswa perempuan dan 9 siswa laki-laki. Variabel bebas pada penelitian ini yaitu model picture and picture. Sedangkan variable terikat yakni pemahaman konsep siswa.

Penelitian ini dilaksanakan pada semester II. Teknik pengumpulan data yang digunakan yaitu observasi dan tes. Analisis data kuantitatif digunakan untuk menghitung besarnya peningkatan pemahaman konsep siswa dengan model picture and picture.

\section{HASIL DAN PEMBAHASAN}

Penelitian tindakan kelas ini dilaksanakan sebanyak empat pertemuan (dua siklus). Disetiap siklusnya terdiri dari tahap perencanaan, pelaksanaan, pengamatan, refleksi. Penelitian ini dilaksanakan mulai tanggal 22 Januari sampai 30 Januari 2020. Penelitian dilaksanakan sesuai prosedur dan skenario pembelajaran yang telah dibuat, selanjutnya rancangan tersebut dipergunakan dalam proses kegiatan belajar mengajar di sekolah sehingga mampu meningkatkan pemahaman konsep para siswa.

Siklus I

Pelaksanaan kegiatan belajar mengajar pada siklus I dilaksanakan mulai tanggal 22 Januari sampai tanggal 23 Januari di SD 2 Jojo dengan jumlah siswa 20 orang. Pada pertemuan pertama siswa meneliti mengenai jenis-jenis pekerjaan lewat cita-cita yang diimpikan para siswa. Siswa diminta menulis biodata masingmasing individu beserta hobi dan cita-cita.

Pada pertemuan kedua siswa sudah mulai mampu membedakan pekerjaan yang berhubungan dengan barang dan jasa secara tidak langsung. Pertemuan kedua siswa mampu mengidentifikasi berbagai pekerjaan melalui potensi sumber daya alam disekitar. Mata pencaharian yang menghasilkan barang kebanyakan berada di wilayah pedesaan, pegunungan dan pesisir. Wilayah perkotaan kebanyakan membutuhkan pekerjaan yang bergerak dibidang jasa misalnya kuli bangunan. Adapun secara lebih rinci, berikut diuraikan hasil penelitian mengenai keterampilan guru dan pemahaman konsep siswa.

\section{Keterampilan Mengajar Guru}

Observasi keterampilan mengajar guru dilakukan oleh Kurniati Styana, S.Pd. Observer melakukan penilaian menggunakan lembar observasi keterampilan guru mengamati aspekaspek keterampilan guru yang mencakup 7 
Amira Henny Mahmudah, Imaniar Purbasari, Ika Ari Pratiwi, dan Erik Aditia Ismaya PICTURE AND PICTURE UNTUK MENINGKATKAN PEMAHAMAN KONSEP JENIS .... WASIS : Jurnal Ilmiah Pendidikan. Volume 2 , Nomor 1, Mei 2021, hlm. 21-28

tahapan model pembelajaran picture and picture yang dilakukan dari awal pembelajaran sampai akhir pembelajaran.

Hasil observasi keterampilan guru dalam menerapkan model picture and picture pada siklus I pertemuan 1 memperoleh nilai rata-rata sebesar 72.62 dengan kategori cukup sedangkan pada pertemuan 2 mengalami peningkatan dengan memperoleh nilai rata-rata sebesar 78,57 namun masih dengan kategori cukup. Keterampilan mengajar guru pada siklus I terjadi peningkatan namun tidak semua indikator mengalami peningkatan. Pertemuan 1 mendapatkan jumlah skor 61 dengan nilai 72,62 dengan kategori cukup, sedangkan pada pertemuan 2 mendapatkan skor 66 dengan nilai 78,57 dengan kategori cukup. Nilai Rata-rata keterampilan mengajar guru sebesar 75,60 dengan kategori cukup.

Nilai rata-rata keterampilan mengajar guru pada siklus I dapat dikatakan sudah mencapai indikator keberhasilan yang ditetapkan yaitu >70. Meskipun sudah mencapai indikator keberhasilan namun pada pelaksanaannya perlu ditingkatkan lagi agar pembelajaran dapat terlaksana dengan optimal.

\section{Pemahaman Konsep Siswa}

Pemahaman konsep siswa dengan model picture and picture dilakukan oleh Yessi Feriani. Pemahaman konsep siswa dapat diketahui keberhasilannya dengan cara menjumlahkan skor yang diperoleh masing-masing siswa kemudian dibagi jumlah skor maksimal dikalikan seratus. Hasil evaluasi pemahaman konsep siswa per indikator dapat diketahui keberhasilannya dengan cara menghitung nilai rata-rata. Jumlah skor per indikator diperoleh dari perolehan jumlah skor siswa. Skor ditentukan oleh peneliti pada setiap butir soal. Setiap soal memiliki skor maksimal yang sama, yaitu skor 4 untuk tiap soalnya.

Hasil evaluasi siklus I pemahaman konsep menunjukkan rata-rata kemampuan pemahaman konsep secara klasikal memperoleh skor rata-rata pertemuan 1 sebesar 67,8 dengan kategori cukup. Sedangkan skor rata-rata kemampuan pemahaman konsep siswa per indikatornya menunjukkan bahwa pada indikator 1) mengintrepretasi (memberikan pendapat) 79: 2) memberi contoh dan non contoh 77; 3) mengklasifikasi objek menurut sifat tertentu sesuai dengan konsepnya 72 ; 4) menggambarkan kesimpulan logis dari informasi yang disajikan 66 ; 5) membandingkan dua hal-hal serupa 64; dan 6) menjelaskan sebab-akibat dari suatu system 66. Nilai rata-rata diperoleh dari jumlah skor siswa dibagi skor maksimal kemudian dikalikan dengan seratus (100). Nilai rata-rata $\leq$ 70 menunjukkan pemahaman konsep siswa belum berhasil.

\section{Refleksi}

Hal-hal yang menjadi catatan untuk perbaikan pada siklus I ditinjau dari beberapa aspek, diantaranya 1) Pada saat proses pembelajaran berlangsung siswa masih belum bisa tertib dan kondusif ketika proses pembelajaran berlangsung, ada beberapa siswa yang sering berbicara sendiri. Agar siswa kondusif guru memberikan menyapa dengan menyanyikan lagu nasional agar siswa kondusif kembali selain itu guru juga harus menegur siswa yang membuat kegaduhan dan mengulang penjelasan materi yang telah disampaikan; 2) Siswa belum mampu bekerja sama dengan kelompoknya, masih terdapat beberapa siswa yang mencatat hasil diskusinya sendiri, ada juga kelompok yang bergantian dalam mencatat hasil diskusi, dan sebagian ada yang berbicara sendiri, sehingga guru harus mengingatkan jika semua kelompok harus berdiskusi dan tidak ada yang berbicara sendiri; 3) Siswa kurang memperhatikan ketika guru menjelaskan petunjuk pengerjaan lembar kerja siswa, sehingga masih banyak siswa yang belum paham dan bertanya. Guru harus mengulang penjelasan mengenai petunjuk pengerjaan lembar kerja siswa; 4) Siswa masih kesulitan dalam menyimpulkan hasil diskusi kelompok dan ada beberapa kelompok yang belum berani untuk mempresentasikan hasil diskusi, sehingga guru harus membantu memberi contoh cara menyimpulkan hasil diskusi dan memotivasi siswa untuk berani mempresentasikan hasil diskusinya; 5) Guru masih kesulitan dalam membagi kelompok, karena siswa menolak berkelompok sesuai data yang telah diberikan guru kelas sehingga siswa gaduh sendiri. Solusinya yaitu guru membagi kelompok sebelum pembelajaran dimulai dan membuat perjanjian jika siswa yang menolak untuk berkelompok akan dikenai sanksi; 6) Guru masih kesulitan dalam membimbing siswa secara berkelompok karena ketika guru membimbing salah satu kelompok maka kelompok lain ramai sendiri dan meminta untuk segera dibimbing. Langkah yang harus dilakukan guru yaitu guru membimbing siswa urut sesuai nama kelompok, dan bergantian; 7) Guru masih kurang memotivasi siswa agar antusias untuk mengikuti pembelajaran. Guru seharusnya dapat memberikan motivasi yang lebih variatif, missal dengan memberikan tepuk semangat kepada 
Amira Henny Mahmudah, Imaniar Purbasari, Ika Ari Pratiwi, dan Erik Aditia Ismaya PICTURE AND PICTURE UNTUK MENINGKATKAN PEMAHAMAN KONSEP JENIS .... WASIS : Jurnal Ilmiah Pendidikan. Volume 2 , Nomor 1, Mei 2021, hlm. 21-28

siswa; 8) Guru masih belum mampu menguasai kelas dengan baik, karena terdapat beberapa siswa yang masih berbicara sendiri bahkan ada yang bermain sendiri dan tidak fokus pada materi yang disampaikan oleh guru. Guru harus bisa memfokuskan siswa pada materi yang disampaikan. Jika ada siswa yang gaduh kemudian guru melempar pertanyaan kepada siswa tersebut, agar fikiran siswa terfokuskan kembali.

Hasil refleksi pada siklus I menunjukkan bahwa pelaksanaan penelitian tindakan kelas pada siklus I belum mencapai indikator keberhasilan yang ditetapkan oleh peneliti terutama pada kemampuan pemahaman konsep. Dengan demikian perlu adanya perbaikan untuk mencapai indikator keberhasilan dengan diadakannya siklus II. Hasil penelitian yang dilakukan memiliki persamaan dan perbedaan dengan riset Agustina, Utaminingsih, dan Purbasari (2014), riset Fadli, Murtono, dan Purbasari (2016), penelitian Triyanto, Sucipto, dan Ismaya, (2017).

Hasil penelitian Agustina,

Utaminingsih, dan Purbasari (2014) menyimpulkan bahwa hasil belajar siswa kelas IV SD 2 Medini Kudus dapat meningkat setelah diterapkannya metode pembelajaran picture and picture. Selanjutnya Hasil riset Fadli, Murtono, dan Purbasari (2016) menemukan bahwa terdapat peningkatan terhadap nilai hasil belajar materi perkerjaan yang cukup signifikan yaitu dari siklus I ketuntasan klasikal sebesar 64,2\% dan meningkat pada siklus II sebesar 92\%. Hasil belajar ranah afektif pada siklus I sebesar $65,7 \%$ meningkat pada siklus II sebesar 87,5\%, kemudian hasil belajar ranah psikomotorik pada siklus I sebesar $68,12 \%$ mengalami peningkatanpada siklus II sebesar $87,79 \%$. Didukung peningkatan keterampilan guru pada siklus I sebesar $81,5 \%$ (Baik) meningkat pada siklusII sebesar $86,3 \%$ (Sangat Baik). Hal tersebut membuktikan bahwa penggunaan model Picture And Picture dapat meningkatkan hasil belajar dan keterampilan guru pada materi pekerjaan kelas III SD Tanjang.

Penelitian Triyanto, Sucipto, dan Ismaya, (2017) menunjukkan bahwa (1) rata-rata persentase aktivitas belajar siswa memperoleh $79,57 \%$ dengan kategori baik pada siklus I dan meningkat menjadi $86,21 \%$ dengan kategori sangat baik pada siklus II. (2) rata-rata persentase hasil belajar ranah afektif $76,32 \%$ pada siklus I dengan kategori baik dan meningkat menjadi $83,12 \%$ dengan kategori baik pada siklus II. Rata-rata persentase hasil belajar ranah psikomotorik $74,45 \%$ pada siklus I dengan kategori baik dan meningkat menjadi 82,64 pada siklus II dengan kategori baik. Nilai tes hasil belajar mencapai kriteria ketuntasan minimal (75) dengan persentase ketuntasan belajar klasikal pada kondisi awal 38,89\% meningkat pada siklus I menjadi $61,11 \%$ dan $77,78 \%$ pada siklus II. Sementara itu riset Astuti, Ahsin, dan Masfuah (2020) menemukan bahwa (1) terjadi peningkatan pemahaman konsep siswa sebelum dan setelah diterapkan model GI berbantuan media Watak Kalinyamatan, (2) Pvalue $=0.039$ $>0.025$ maka HO diterima, artinya rata-rata nilai posttest pemahaman konsep siswa melalui model GI berbantuan media Watak Kalinyamatan mendapatkan nilai $\geq 65$, (3) aktivitas belajar siswa pertemuan 2,3 dan $4 \mathrm{P}$-value $=0.1075$, 0.045 , dan $0.037 \geq 0,025$ maka H0 diterima, artinya aktivitas siswa setelah diberikan pembelajaran melalui model GI berbantuan media Watak Kalinyamatan $\geq 65$.

\section{SIKLUS II}

Pelaksanaan kegiatan belajar mengajar pada siklus II dilaksanakan mulai tanggal 29 Januari sampai tanggal 30 Januari 2020 di SD 2 Jojo dengan jumlah siswa 20 orang. Pertemuan ketiga mengajarkan tentang materi pekerjaan orangtua. Para siswa sudah mulai mampu membedakan jenis-jenis pekerjaan yang menghasilkan barang dan jasa. Siswa sudah mulai mapu mengidentifikasi pekerjaan yang menghasilkan barang dan jasa melalui pekerjaan orang tua.

Pekerjaan yang menghasilkan barang seperti petani dan peternak berhubungan dengan pengolahan sumber daya alam. Pekerjaan yang menghasilkan jasa antara lain seperti buruh pabrik, penjual, penambang, supir, tengkulak dan tukang bangunan berhubungan dengan sumber daya manusia.

Sumber daya alam dan sumber daya manusia mempengaruhi hubungan kegiatan ekonomi. Pada pertemuan keempat materi yang diajarkan yakni contoh kegiatan ekonomi. Para siswa diminta mengindentifikasi gambar. Para siswa diminta mengurutkan gambar. Siswa telah berhasil mengidentifikasi kegiatan ekonomi dari gambar. Tujuannya yaitu agar siswa memperoleh pembelajaran konkret disekitar melalui gambar kegiatan ekonomi yang di sajikan.

\section{Keterampilan Mengajar Guru}

Hasil keterampilan mengajar guru di siklus II pertemuan 1 dan pertemuan 2 mengalami peningkatan di setiap indikatornya. Pertemuan 1 mendapatkan nilai rata-rata sebesar 
Amira Henny Mahmudah, Imaniar Purbasari, Ika Ari Pratiwi, dan Erik Aditia Ismaya PICTURE AND PICTURE UNTUK MENINGKATKAN PEMAHAMAN KONSEP JENIS .... WASIS : Jurnal Ilmiah Pendidikan. Volume 2 , Nomor 1, Mei 2021, hlm. 21-28

80,95 dengan kategori baik, sedangkan pada pertemuan 2 mendapatkan nilai rata-rata sebesar 85,71 dengan kategori baik. Nilai rata-rata keterampilan mengajar guru pada siklus II mendapatkan nilai rata-rata sebesar 83,93 sehingga dapat dikategorikan baik atau di atas indikator keberhasilan yang ditetapkan yakni $\geq 70$.

Keterampilan mengajar guru pada hasil observasi siklus II sudah menunjukkan peningkatan pada setiap indikatornya, namun tidak semuanya meningkat tetapi tidak ada indikator yang mendapatkan skor menurun. Peningkatan keterampilan mengajar guru terjadi di setiap indikator antara siklus I ke siklus II. Keterampilan mengajar guru pada siklus II terjadi peningkatan dan secara umum guru sudah menerapkan langkah-langkah model pembelajaran picture and picture dengan baik. Berdasarkan hasil penilaian keterampilan mengajar guru memperoleh hasil bahwa pelaksanaan pembelajaran pada siklus II sudah berhasil.

\section{Pemahaman Konsep Siswa}

Hasil evaluasi siklus II pemahaman konsep menunjukkan rata-rata kemampuan pemahaman konsep secara klasikal memperoleh skor rata-rata sebesar 75 dengan kategori baik. Sedangkan skor rata-rata kemampuan pemahaman konsep siswa per indikatornya menunjukkan bahwa pada indikator 1) mengintrepretasi (memberikan pendapat) $80 ; 2$ ) memberi contoh dan non contoh 79 ; 3) mengklasifikasi objek menurut sifat tertentu sesuai dengan konsepnya 76; 4) menggambarkan kesimpulan logis dari informasi yang disajikan 74; 5) membandingkan dua hal-hal serupa 71; dan 6) menjelaskan sebab-akibat dari suatu system 70. Hasil observasi siklus II pemahaman konsep menunjukkan rata-rata kemampuan pemahaman konsep secara klasikal memperoleh skor rata-rata sebesar 75 dengan kategori baik. Nilai rata-rata diperoleh dari jumlah skor siswa dibagi skor maksimal kemudian dikalikan dengan seratus (100). Nilai rata-rata $\geq 70$ menunjukkan pemahaman konsep siswa sudah berhasil.

\section{Refleksi}

Setelah pelaksanaan tindakan pada siklus II peneliti melakukan refleksi terhadap kegiatan pembelajaran yang telah dilakukan. Secara keseluruhan kegiatan pembelajaran pada siklus II sudah berjalan dengan baik dan memenuhi target yang telah ditentukan oleh peneliti. Pada kegiatan pembelajaran siklus II siswa lebih aktif dan antusia, hal tersebut dikarenakan guru lebih mampu menguasai kelas dan menumbuhkan semangat siswa untuk mengikuti proses pembelajaran. Namun masih terdapat 4 siswa yang masih belum tuntas dalam evaluasi siklus II. Hal tersebut dikarenakan 4 siswa tersebut sering berbicara sendiri dengan temannya dan jarang memperhatikan penjelasan dari guru.

Keterampilan guru menggunakan model picture and picture untuk meningkatkan pemahaman konsep siswa dan hasil pengamatan keterampilan mengajar guru dapat disimpulkan bahwa pelaksanaan siklus II sudah berhasil karena telah mencapai indikator keberhasilan. Oleh karena itu penelitian tidak dilakukan tindakan pada siklus selanjutnya.

Hasil penelitian yang dilakukan memiliki persamaan dan perbedaan dengan riset Nafi'an, Hayuhantika, dan Nur (2017); penelitian Irawan AS, Setiawan, dan Ismaya (2018), riset Nurhidayat, Purbasari, dan Ahsin (2019); penelitian Hakiki, Ekowati, dan Susintowati, (2019). Persamaan yang dimaksud yaitu pemilihan model pembelajaran picture and picture dan pemahaman konsep sebagai variabel penelitian. Adapun perbedaannya yakni pada subjek penelitian, tempat, waktu, serta hasil penelitian yang diperoleh.

\section{SIMPULAN}

Berdasarkan analisis hasil penelitian tindakan kelas di kelas IV SD 2 Jojo Kudus dengan menggunakan model picture and picture pada pembelajaran jenis mata pencaharian di lingkungan. Pemahaman konsep melalui tahap pertama yaitu mengidentifikasi pekerjaan melalui cita-cita yang ingi dicapai, tahap kedua yaitu dengan mengidentifikasi pekerjaan melalui lingkungan yang disajikan, tahap ketiga mengidentifikasi pekerjaan melalui pekerjaan orang tua yang dapat menghasilkan barang atau jasa, tahap terakhir adalah mengidentifikasi melalui kegiatan ekonomi dari gambar yang disajikan.

Kegiatan ekonomi dipengaruhi oleh pekerjaan yang menghasilkan barang melalui pengolahan sumber daya alam yang disebut produksi. Sumber daya manusia juga ikut mempengaruhi kegiatan ekonomi melalui pekerjaan yang berhubungan dengan jasa. Kegiatan ekonomi dibagi 3 yaitu produksi (menghasilkan barang), distribusi (penyalur barang), dan konsumsi (memperoleh suatu barang).

Data hasil observasi pemahaman konsep siswa dengan menggunakan model picture and picture pada pembelajaran jenis mata 
Amira Henny Mahmudah, Imaniar Purbasari, Ika Ari Pratiwi, dan Erik Aditia Ismaya PICTURE AND PICTURE UNTUK MENINGKATKAN PEMAHAMAN KONSEP JENIS .... WASIS : Jurnal Ilmiah Pendidikan. Volume 2 , Nomor 1 , Mei 2021, hlm. 21-28

pencaharian di lingkungan sekitar di kelas IV SD 2 Jojo Kudus menunjukan bahwa dalam meningkatkan pemahaman konsep siswa dengan menggunakan model picture and picture pada pembelajaran jenis mata pencaharian muatan IPS di lingkungan sekitar di kelas IV SD 2 Jojo Kudus, siklus I $75 \%$ meningkat $19 \%$ menjadi $94 \%$ di siklus II.

\section{DAFTAR PUSTAKA}

Agustina, Mira., Utaminingsih, Sri., dan Purbasari, Imaniar. 2014. Penerapan Metode Pembelajaran Picture And Picture Dalam Meningkatkan Hasil Belajar Siswa Kelas IV SD 2 Medini Kudus Pada Mata Pelajaran IPS Tahun 2013/2014. Skripsi. Kudus: Universitas Muria Kudus.

Arikunto, Suharsimi. 2009. Dasar-dasar Evaluasi Pendidikan. Jakarta: Bumi Aksara.

Arikunto, Suharsimi dkk. 2006. Penelitian Tindakan Kelas. Jakarta Bumi Aksara.

Astuti, Nurlaely Dwi., Ahsin, Muhammad Noor dan Masfuah, Siti. 2020. Efektivitas Model Group Investigation Berbantuan Media Watak Kalinyamatan Terhadap Pemahaman Konsep Siswa. WASIS: Jurnal Ilmiah Kependidikan, 1 (2): 60-67.

Daryanto. 2011. Manajemen Pemasaran. Bandung: PT Sarana Tutorial NuraniSejahtera.

Daryanto. 2013. Media Pembelajaran Perannya Sangat Penting dalam Pembelajaran. Jogjakarta: Gava Media.

Dimyati dan Mudjiono. 2009. Belajar dan Pembelajaran. Jakarta: PT Rineka Cipta.

Fadli, Fakih Islah., Murtono., Murtono., dan Purbasari, Imaniar. 2016. Penerapan Model Picture And Picture Dalam Upaya Meningkatkan Hasil Belajar Pada Mata Pelajaran IPS Materi Perkerjaan Terhadap Siswa Kelas III SD TANJANG. Skripsi. Kudus: Universitas Muria Kudus.

Hakiki, Farhatul., Ekowati, Dyah Worowirastri., dan Susintowati, Wiwik. 2019. Peningkatan Pemahaman Konsep Nilai Tempat Bilangan Melalui Media Gelas Warna Pada SISWA Kelas I SDN Purwantoro 2 Malang.
REFLEKSI EDUKATIKA : Jurnal Ilmiah Kependidikan, 9 (2): 223-228.

Hamalik, Oemar. 2011. Kurikulum dan Pembelajaran. Jakarta: Bumi Aksara.

Irawan AS, Moh Danu., Setiawan, Deka., dan Ismaya, Erik Aditia. 2018. Penerapan Model Pembelajaran Picture And Picture Terhadap Kemampuan Berpikir Kritis Siswa Pada Pembelajaran IPS Kelas V SDN 02 Sumbermulyo Pati. Skripsi. Kudus: Universitas Muria Kudus.

Nafi'an, Muhammad Ilman., Hayuhantika, Diesty., dan Nur, Afifah Dian Septi. 2017. Kemampuan Mahasiswa PGSD Dalam Mengonstruksi Pemahaman Konsep Aljabar Berdasarkan Teori APOS. REFLEKSI EDUKATIKA : Jurnal Ilmiah Kependidikan, 8 (1): 74-79.

Ndraha, Taliziduhu. 1991. Dimensi-Dimensi Pemerintahan Desa. Jakarta: PT Bumi Aksara.

Noer Rahmah. 2012 Psikologi Pendidikan. Yogyakarta: Teras.

Nurcahyaningtyas. 2009. Ekonomi Untuk Kelas X SMA/MA. Jakarta : Pusat Perbukuan, Departemen Pendidikan Nasional.

Nurhidayat, Rahmat Alif., Purbasari, Imaniar., dan Ahsin, Muhammad Noor 2019. Penerapan Model Picture And Picture Berbantuan Media Gambar untuk Meningkatkan Hasil Belajar Siswa Pada Tema 1 Muatan Bahasa Indonesia dan IPS Kelas V SDN Widorokandang Pati. Skripsi Kudus: Universitas Muria Kudus.

Poerwadarmitra. 2002. Proyeksi Kerja Dengan Metode Campuran. Jurnal Bekala Ilmiah, 2 (1).

Slamet, Mohammad. 2019. Development of Learning Media Picture Books Based On Local Wisdom Kudus Indonesian Language Subjects Poetry Writing Material for Grade V Students of Primary Schools. REFLEKSI EDUKATIKA : Jurnal Ilmiah Kependidikan, 10 (1): 97-104.

Sudjana, Nana. 1990. Metode dan Teknik Pembelajaran. Bandung: Falah Production. 
Amira Henny Mahmudah, Imaniar Purbasari, Ika Ari Pratiwi, dan Erik Aditia Ismaya PICTURE AND PICTURE UNTUK MENINGKATKAN PEMAHAMAN KONSEP JENIS ... WASIS : Jurnal Ilmiah Pendidikan. Volume 2 , Nomor 1 , Mei 2021, hlm. 21-28

Sudijono, Anas. 2011. Pengantar Evaluasi Pendidikan. Jakarta: PT Rajagrafindo Persada

Syah, Muhibbin. 2007. Psikologi Pendidikan Dengan Pendekatan Baru. $\quad$ Bandung: PT Remaja Rosdakarya.

Triyanto, Achmad., Sucipto, Sucipto., dan Ismaya, Erik Aditia. 2017. Peningkatan Hasil Belajar Siswa Melalui Model Picture And Picture Pada Pembelajaran IPS Kelas IV SDN 2 Bakalan Krapyak. Skripsi. Kudus: Universitas Muria Kudus.

Widianti, Wida dan Hurriyati, Ratih. 2009. Ilmu Pengetahuan Sosial untuk Sekolah Dasar dan Madrasah Ibtidaiyah kelas III. Jakarta : Pusat Perbukuan, Departemen Pendidikan Nasional.

Widjajanta, Bambang dan Aristanti Widyaningsih. 2009. Mengasah Kemampuan Ekonomi 1 Untuk Kelas X Sekolah Menengah Atas/Mandrasah Aliyah Program Ilmu Pengetahuan Sosial. Jakarta : Pusat Perbukuan, Departemen Pendidikan Nasional.

Wahyu Istanti, Adriani dan Triwidjaja. 2014. Penerapan Model Pembelajaran Picture and Picture Pada Pembelajaran IPA Anak Tunagrahita SDLB. Jurnal P3LB, 1 (2): 169-174. 